\title{
Correction to: Effects of the sintering process on the different properties of alumina/hydroxyapatite nanobiocomposites
}

\author{
Smain Bezzina ${ }^{1} \cdot$ Ahmed B. Khoshaim $^{2}$
}

Published online: 7 June 2021

(c) The Author(s), under exclusive licence to Springer-Verlag GmbH, DE part of Springer Nature 2021

Correction to: Applied Physics A (2021) 127:428

https://doi.org/10.1007/s00339-021-04557-y

In the original publication of the article, the corresponding author's name was incorrect. The correct name is Smain Bezzina, not Smain Bezzin.

Publisher's Note Springer Nature remains neutral with regard to jurisdictional claims in published maps and institutional affiliations.

The original article can be found online at https://doi.org/10.1007/ s00339-021-04557-y.

Smain Bezzina

bezzina390@gmail.com

1 Deanship of Scientific Research, King Abdulaziz University, Jeddah, Saudi Arabia

2 Mechanical Engineering Departments, Faculty of Engineering, King Abdulaziz University (KAU), P.O. Box 80204, Jeddah, Saudi Arabia 